\title{
IMPORTANT WOODY SPECIES IN POODŘÍ FLOODPLAINS (CZECH REPUBLIC)
}

\author{
PETRA RYCHTECKÁ ${ }^{1,2}$, JAROMÍRA DRESLEROVÁ ${ }^{2}$ \\ ${ }^{1}$ Forest management institute, Brandýs nad Labem, branch Frýdek-Mistek, 73801 Frýdek- \\ Místek, Nádražní 2811, Czech Republic \\ ${ }^{2}$ Department of Forest Botany, Dendrology and Geobiocoenology, Mendel University of \\ Agriculture and Forestry, 61300 Brno, Zemédělská 3, Czech Republic, \\ E-mail: petra.rychtecka@seznam.cz,petra.rychtecka@uhul.cz
}

Received: $17^{\text {th }}$ March 2008, Accepted: $17^{\text {th }}$ August 2009

\begin{abstract}
The aim of this paper is to describe the species biodiversity of important woody species in the riparian zone of wide floodplains in the Protected Landscape Area (PLA) Poodří (Central Europe, Czech Republic). The analysis of growth in terms of particular species was carried out to find out their growth potential. Another task was to evaluate the diversity and health condition of all trees and to determine the occurrence frequency of important woody species (IWS) in particular geobiocoene type groups of wide alluvial plains. The tree classification pyramid (veteran-representative-successor-expectant) was built up to provide the sufficient number of diverse IWS in the area. In total, 3,419 IWS were mapped in the whole area of the PLA Poodři $\left(81.5 \mathrm{~km}^{2}\right)$. In wide alluvial plains, the Ulmi-fraxineta carpini sup. geobiocoene type group (GTG) shows the highest diversity. According to the surveys carried out in the area under investigation it is evident that there are a lot of IWS here deserving protection and the proposal of the appropriate management, which should be represented by the pyramid mentioned above. The pyramid would provide protection and care for the registered trees to reach a respectable age and maximum dimensions. It is necessary to preserve the species spectrum of the IWS to maintain the gene pool of initial populations and biodiversity in landscape. Some species exceed growth parameters of the same species at other floodplain sites in the Czech Republic and even in Europe.
\end{abstract}

Keywords: floodplain forests, important woody species, growth potential, geobiocoenosis

\section{INTRODUCTION}

Floodplain communities belong among very rare and endangered ecosystems. Landscape/ecological functions of the communities in alluvial plains are quite irreplaceable (Bornette, 1996). The Protected Landscape Area Poodří (PLA Poodří) represents a unique preserved mosaic landscape of a wide alluvial plain with much diversified biocoenoses. Although present floodplain forests do not show natural structure, their character is closeto-nature. In the landscape sphere, the forests function as irreplaceable components of the environment (Wagner, 1990).

Floodplain forests show specific vegetation of azonal character, which is the result of present effects of the high groundwater level and seasonal floods (Anderson, 1996). In 
Central Europe, floodplain forests occurred naturally in valley regions along all rivers creating main communities of the lowest locations (Korpel', 1989).

Thanks to floodplain soils rich in nutrients and high groundwater level trees reach extraordinary dimensions (Malanson, 1995). Important woody species (IWS) are those trees, which excel due to their dimensions in the given locality helping to create the character of the landscape by their uniqueness and presence (Maděra, 2002). According to Lonsdale (1999), it is an old and valuable tree, in which we can assume that it survives the typical age range of the given species. Read (2000) specified trees, which were interesting from biological, aesthetic and cultural aspects because they reached certain age, dimensions and condition as veterans.

The databank of information on big trees in open landscape is not sufficient yet. Only "memorable trees" are registered. Basic information on proclaimed "memorable trees" is included in the "Central list" of the Agency for Nature Conservation and Landscape Protection in Prague (Reš, 1998). The first list of remarkable trees in Bohemia, Moravia and Silesia was published by Jan Evangelista Chadt Ševínský (1913), who described 320 rare trees in his book. This list, which has been prepared with the aid of a number of contributors, is the first detailed list of memorable trees in our country.

Holobrádek (1952, 1958) referred to IWS of the genus Quercus in the Dyje-Morava floodplain. Numerous field surveys and searching for IWS in the valley of the Dyje river (areas of the Vienna basin and of the Dyje-Svratka valley in the northern foreground of the Alpine geotectonical system) were the follow-up of the author (Dečmar, 1969; Polehla, 2002; Brzobohatý, 2000; Suchyňová, 2002; Polišenská, 2002; Maděra et al. 2006). Description of the diversity of selected IWS allowed specification of ecologically significant segments of landscape and formulation of nature conservation approaches (Jongman et al., 2004).

\section{MATERIAL AND METHODS}

The aim of the paper is to describe the species diversity of IWS in the riparian zone of wide alluvial plains, to carry out the analysis of their growth within particular species and, thus, to determine their potential growth possibilities. Information on the species diversity and frequency of IWS was divided according to the occurrence of particular specimens of IWS on specific sites defined as geobiocoene type groups (GTG). Thus, it was possible to evaluate the growth potential of IWS in relation to site properties. The classification of GTG was carried out according to definitions of Buček, Lacina (1999) and Culek (1996) (Tab. 1).

Field survey was carried out in the area of the PLA Poodří, which is situated on foothills of the outer Western Carpathians (the Moravian Gate) between the margin of the Bohemian Massive and orogene of the Western Carpathians (Fig. 1). The studied area is of alluvial character due to the Odra River. The river shows preserved meandering stream there in alternating aeolian and alluvial sediments. The altitude of the area ranges between 212 and $298 \mathrm{~m}$. The forest cover percentage of the PLA Poodří is about 10\% (Rychtecká, 2004). A great deal of IWS is concentrated in riparian stands, which conditions the landscape character and affects their distribution and frequency. Therefore, the field survey was focussed on the evaluation of IWS occurring in natural formations of riparian stands or floodplain forests as well as on their occurrence in the anthropogenic enclaves of dams, in meadows, arable land and in built-up areas. 
Table 1: Potential vegetation of the Podbeskydský bio-region (according to Culek, 1996)

\begin{tabular}{|l|l|l|}
\hline \multicolumn{2}{|c|}{ Potential vegetation } \\
\hline \multicolumn{1}{|c|}{ Terrain } & \multicolumn{1}{|c|}{ Zonal } & \multicolumn{1}{c|}{ Azonal } \\
\hline \multirow{5}{*}{ Lowland } & Tilio cordate-Carpinetum & Pruno-Fraxinetum \\
\cline { 2 - 3 } & Luzulo albidae-Quercetum & Agrostio-Salicetum purpureae \\
\cline { 2 - 3 } & Carici-Quercetum & \\
\hline \multirow{3}{*}{ Upland } & Dentario enneaphyli-Fagetum & Arunco sylvestris-Alnetum glutinosae \\
\cline { 2 - 3 } & Dentario glandulosae-Fagetum & \\
\cline { 2 - 3 } & Aceri-Carpinetum & \\
\hline Submontane & Eu-Fagenion & Salicion eleagni \\
\cline { 2 - 3 } & Festuco-Fagetum & Carici remotae-Fraxinetum \\
\hline
\end{tabular}

Fig.1: Observed area of the PLA Poodří

Bohemian Massif: 1 - Nízký Jeseník Mts.

Western Carpathians: 2 - Extended Carpathian Depression (Moravian Goal), 3 - Extended Western Carpathions (Podbeskydská Higlands), 4 - North Extended-Carpathion Depression (Ostrava Basin)

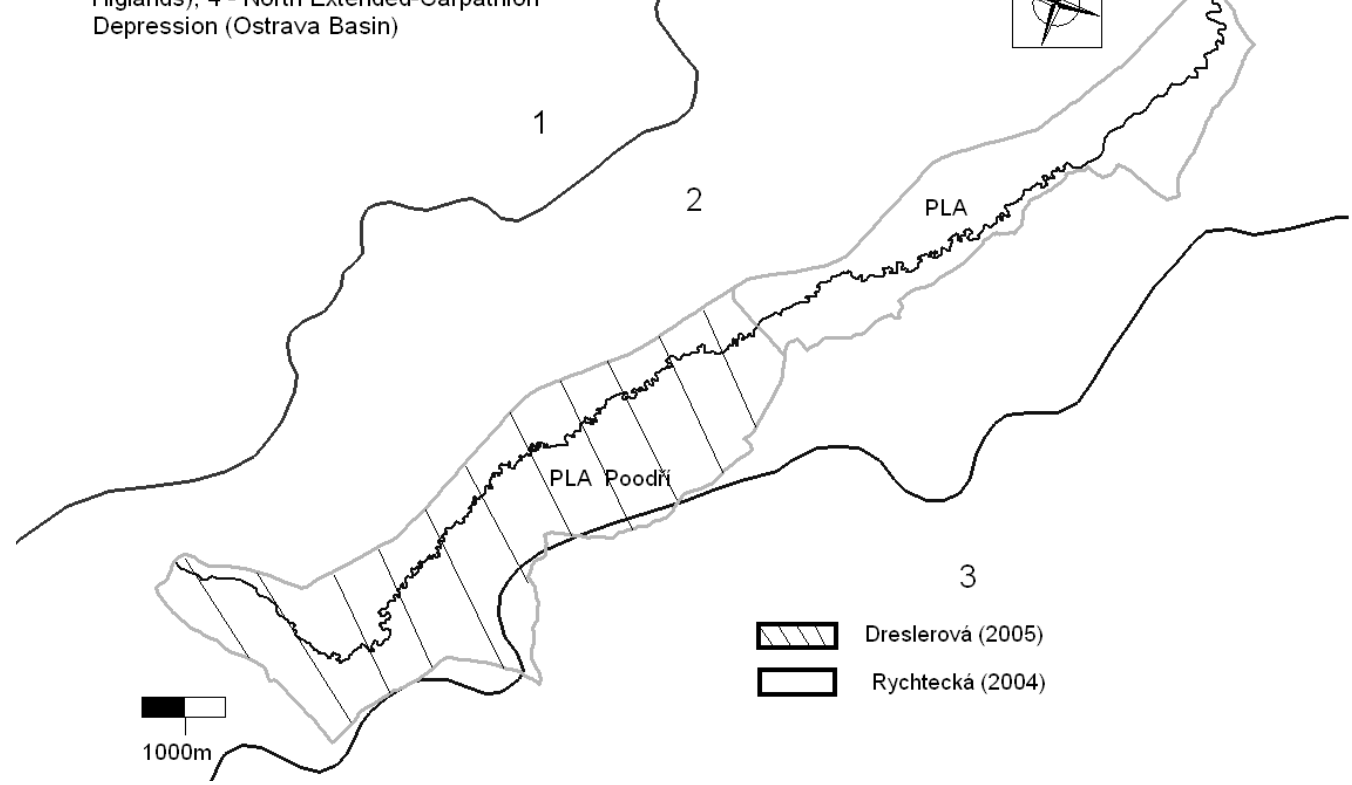

The field survey was carried out during summer in 2002 - 2004. It continued in the previous geobiocoenological mapping. In the riparian zone of the Odra River, the area of the stream and its 7 tributaries was geobiocoenologically mapped (river km 22.000 75.330) (Tab. 2). Along the streams, six GTG were delimitated: Saliceta fragilis inf., Alni glutionosae-saliceta sup., Ulmi-fraxineta carpini sup., Ulmi-fraxineta populi sup., Querci roboris-fraxineta sup. and contact GTG (Buček et al., 2000) (Tab. 3). 
Table 2: Trees registered according to a watercourse with a determined GTG

\begin{tabular}{|c|c|}
\hline Name of the watercourse & Number of registered trees \\
\hline Odra & 746 \\
\hline Jičínka & 7 \\
\hline Luha & 24 \\
\hline Husí potok & 6 \\
\hline Lubina & 23 \\
\hline Ondřejnice & 12 \\
\hline Sedlnice & 0 \\
\hline Bílovka & 0 \\
\hline & $\sum 818$ \\
\hline
\end{tabular}

Table 3: Characteristics of GTG in the riparian zone of the PLA Poodří (wide valley floodplains; Buček, Lacina, 1999)

\begin{tabular}{|c|c|}
\hline \multicolumn{2}{|l|}{ Saliceta fragilis inf. (3 B-C 5a) } \\
\hline Ekotope & Potential vegetation \\
\hline $\begin{array}{l}\text { Gravel-sand alluvia along banks of streams } \\
\text { and rivers, river islands, alt. } 250 \text { to } 500 \mathrm{~m} \text {, } \\
\text { the youngest parts of the river floodplain, soil } \\
\text { type: Skeletic Fluvisols }\end{array}$ & $\begin{array}{l}\text { The youngest stages of the development of } \\
\text { floodplain communities of uplands and } \\
\text { highlands } \\
\text { Salicion triandrae, Salicion albae }\end{array}$ \\
\hline \multicolumn{2}{|c|}{ Alni glutinosae-saliceta superiora (2-3 BC 5b) } \\
\hline $\begin{array}{l}\text { Depressions with reduced runoff, wide river } \\
\text { floodplains, Stagnic Gleysols }\end{array}$ & $\begin{array}{l}\text { Succession-developed communities of alder } \\
\text { forets, } \\
\text { Carici elongatae-Alnetum }\end{array}$ \\
\hline \multicolumn{2}{|c|}{ Ulmi-fraxineta carpini sup. (2-3 BC-C (3)4) } \\
\hline $\begin{array}{l}\text { Relatively the driest parts of wide river } \\
\text { floodplains, up to } 250 \mathrm{~m} \text { alt. (exceptionally } \\
\text { even } 280 \mathrm{~m} \text { ), groundwater table usually } \\
\text { deeper than } 150 \mathrm{~cm} \text {, soil type: Maplic } \\
\text { Fluvisols }\end{array}$ & $\begin{array}{l}\text { Species-rich community of a floodplain } \\
\text { forest on a transition to surrounding } \\
\text { broadleaved forests at hydric-normal sites, } \\
\text { Querceto-Ulmetum }\end{array}$ \\
\hline \multicolumn{2}{|l|}{ Ulmi-fraxineta populi sup. (2-3 C (4)5a) } \\
\hline $\begin{array}{l}\text { up to } 250 \mathrm{~m} \text { alt., exceptionally up to } 300 \mathrm{~m} \text {, } \\
\text { under natural conditions regularly inundated, } \\
\text { soil type: Arenic Fluvisols }\end{array}$ & Querceto-Ulmetum \\
\hline \multicolumn{2}{|c|}{ Querci roboris-fraxineta sup. (2-3 BC-C (4)5a) } \\
\hline $\begin{array}{l}\text { Wide river floodplains, up to } 200 \text { - } 250 \mathrm{~m} \text { alt. } \\
\text { locations relatively remote from } \\
\text { watercourses where sedimentation of finer } \\
\text { clay particles occurs during floods, soil type: } \\
\text { Gleyic Fluvisols }\end{array}$ & Querceto-Ulmetum \\
\hline
\end{tabular}

IWS were registered if minimal girth reached $2 \mathrm{~m}$ at the breast height of $1.3 \mathrm{~m}$. Exceptions were made for Alnus glutinosa (L.) Geartn., Acer campestre L. and Carpinus betulus Z., which were already registered at the minimum girth of $1 \mathrm{~m}$. In registered trees, 
following parameters were measured: height $(h)$, girth at breast height $(\mathrm{GBH})$, crown height, health condition according to a 6-degree classification (Tab. 4), occurrence of mutualists and parasites. The site of every registered tree was classed according to geobiocoenological map sources (Buček et al., 2000).

Table 4: Classification of health condition (Rychtecká, 2004)

\begin{tabular}{|c|c|c|}
\hline 1 & Excellent & Vital, free of visible damage, \\
\hline 2 & Very good & Healthy, small damage, drying up to $10 \%$ \\
\hline 3 & Slightly damaged & $\begin{array}{l}\text { Occurrence of cavities of cambioxylophagous insect, drying up to } \\
11-25 \%\end{array}$ \\
\hline 4 & Markedly damaged & $\begin{array}{l}\text { Heavy damage by abiotic agents, man, wood-destroying fungi, , } \\
\text { cambioxylophagous insect, drying up to } 51-99 \%\end{array}$ \\
\hline 5 & Dying & Decay, stem decay, drying up to 51-99\% \\
\hline 6 & Dead & Non-viable, torso, dry \\
\hline
\end{tabular}

Table 5: Characteristics of particular stages of the physiological age of registered trees (Read, 2000)

\begin{tabular}{|c|c|}
\hline Stage & Characteristics \\
\hline \multicolumn{2}{|l|}{ A-seedling } \\
\hline \multicolumn{2}{|l|}{ B-sapling } \\
\hline $\begin{array}{l}\text { C to D } \\
\text { full to late } \\
\text { maturity }\end{array}$ & $\begin{array}{l}\text { Cessation of the length increment in the tree crown, rounding the } \\
\text { crowns, loss of vitality in the peripheral zone of a crown, initialization } \\
\text { of regeneration processes in lower parts of a crown and stem, } \\
\text { colonization of dead wood by saprophytic invertebrates, maximum } \\
\text { production of pollen and fertility, increasing the volume of non- } \\
\text { functional tissues, acceleration of colonization by fungi and their } \\
\text { activities }\end{array}$ \\
\hline $\begin{array}{l}D \text { to } E \\
\text { early old age }\end{array}$ & $\begin{array}{l}\text { Reduction of the net annual increment of wood, decreasing the living } \\
\text { part of a crown and reducing the growth vitality of crowns, increasing } \\
\text { the activity of fungi and wood decomposition, the origin of cavities, } \\
\text { increasing the colonization of dead wood by lower plants and animals }\end{array}$ \\
\hline $\begin{array}{l}\mathrm{E} \text { to } \mathrm{F} \\
\text { late old age }\end{array}$ & $\begin{array}{l}\text { Continued reduction of a crown, decreasing the size of a crown and } \\
\text { annual increment, origin of cavities, break-down of a crown, decreasing } \\
\text { the tree vitality, increasing the wood decomposition, activities of fauna } \\
\text { and flora }\end{array}$ \\
\hline $\begin{array}{l}\mathbf{F} \text { to } \mathbf{G} \\
\text { senescence }\end{array}$ & $\begin{array}{l}\text { Final disintegration of a tree, continued activities of fungi, the } \\
\text { culmination of wood-destroying activities and the return of nutrients } \\
\text { into soil, fragmentation of the tree stem to small parts }\end{array}$ \\
\hline
\end{tabular}




\begin{tabular}{|l|l|l|}
\hline $\begin{array}{l}\text { Physiological } \\
\text { vitality }\end{array}$ & Strategy & Characteristics \\
\hline 1-Full & Growth & All energy is invested in the tree growth \\
\hline 2-Sufficient & Defence & $\begin{array}{l}\text { Part of the energy is spent to defence at the expense of } \\
\text { growth, which is retarded }\end{array}$ \\
\hline 3-Insufficient & Survival & $\begin{array}{l}\text { All energy is spent for survival, cessation of growth, } \\
\text { fructification, restoration of energy balance is difficult or } \\
\text { even impossible }\end{array}$ \\
\hline 4-None & $\begin{array}{l}\text { Irreversible disturbance of energy balance and dieback } \\
\text { of a tree }\end{array}$ \\
\hline 5-Dead & Dead tree \\
\hline
\end{tabular}

Vitality and physiological age of woody species served as dendro-ecological parameters. From the viewpoint of determining the rate of damage and thus the supposed prospect of a tree, the actual age of a tree is not too important for evaluation but rather its developmental stage. Instead of age the characteristics is termed "physiological age" of a tree (Berker, 1977). Thus, a scale for the evaluation can be as follows. Physiological age and vitality according to Read (2000) (see Tab. 5).

Findings obtained were used for the proposal of suitable sustainable management or the way of care for big trees in the studied area in order to ensure their existence in the same or higher proportion (density) in the model area for a long time. The methodical framework to deal with the task is represented by principles of sustainable care for IWS. Individual IWS were divided into four categories on the basis of their importance, minimal girth, health condition, vitality a physiological age (Read, 2000): veterans (V), representatives (R), successors (S) and candidates (C).

Trees, which are exceptional at excessive parameters in GBH compared to other trees of the same species or trees, which are otherwise exceptional particularly due to their age belong to the category of veterans. In trees of this category, health condition and the degree of vitality are not decisive. Unambiguously, it refers to trees in which the final disintegration and death of the tree occur. Trees with above-average dimensions or otherwise exceptional belong to the category of representatives. The GBH minimum limit for particular species to include a tree into the category has to be determined gradually and empirically. As a rule, representatives are from early age characterized by reduced vitality. Allochthonous species should not be ranked among veterans or representatives. Trees which have not yet reached excessive dimensions but show excellent health conditions and vitality are termed successors. It concerns fully mature trees, partly more vital individuals from the stage of early old age. It is supposed that they reach large dimensions to become representatives or even veterans in the near future. The candidates are the last category, where other trees in the stage of full maturity or early old age are concentrated. Thus, both fully vital, sufficiently vital and insufficiently vital trees reaching average dimensions are included.

\section{RESULTS}

\section{Diversity of IWS}

Through the inventory of IWS in the whole area of $81.5 \mathrm{~km}^{2}$ of the Poodrí PLA some 3,374 IWS were mapped. The database amounts to 26 various species and hybrids +4 
species- unspecified genera Malus sp. Mill, Betula sp. L., Populus sp. L. and Salix sp L.. The genus poplar (Populus sp. L.) includes undifferentiated species of black poplar (Populus nigra L.) and hybrids of Populus $x$ canadensis Moench. The term Salix sp. L. includes trees of arborescent willows (Salix fragilis L., Salix alba L. and Salix $x$ rubens Schrank), which have not been clearly and undoubtedly determined. Some 19 species and one hybrid (Salix $x$ rubens Schrank) belong to autochthonous species. Remaining 4 species and 2 hybrids belong to allochthonous species. It refers to Aesculus hippocastanum L., Platanus $x$ acerifolia (Aiton) Willd., Populus balsamifera L., Populus $x$ canadensis Moench, Quercus rubra L. and Robinia pseudoacacia L.. The proportion of species is as follows: Quercus robur L. 1,110 trees (33\% of the total number), Salix alba L. 418 trees and Fraxinus excelsior L. 388 trees (Tab. 6).

\section{Proportion of IWS according to the biotope type}

From the viewpoint of the biotope type most IWS occurs in the riparian zone of a watercourse $(33 \%)$, almost the same proportion (32\%) falls within forest stands and the third most numerous biotope with $17 \%$ includes stands on banks of ponds, groves include $11 \%$ IWS. The smallest proportion falls in meadows (4\%), built up areas $(2 \%)$ and arable land (1\%), where solitary trees occur (Fig. 2).

Fig.2: Proportion of IWS in particular biotopes in the area of the PLA Poodří

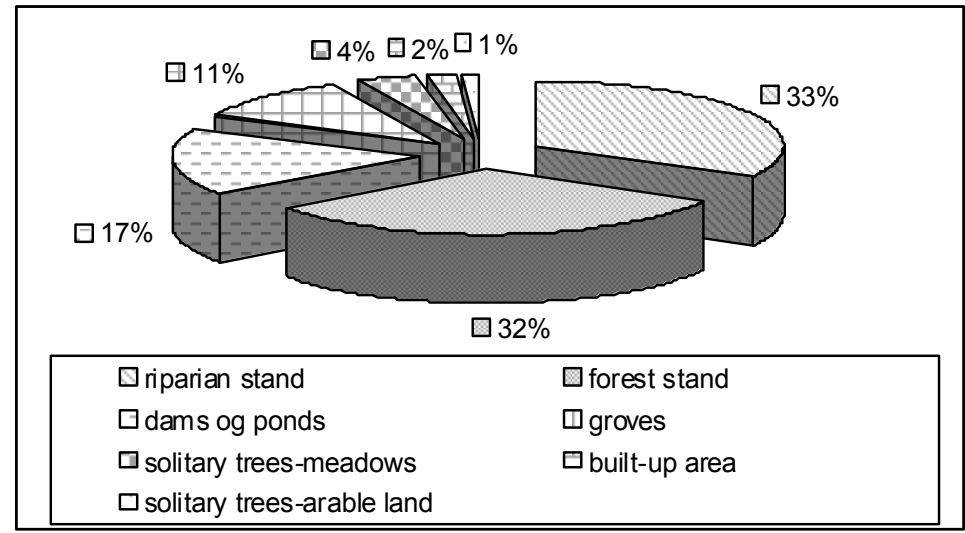

\section{Growth parameters}

Salix alba L. with GBH $720 \mathrm{~cm}$ and height $15 \mathrm{~m}$, Ulmus laevis Pallas with GBH of620 $\mathrm{cm}$ and height of $33 \mathrm{~m}$ - both trees growing on the bank of the Odra River and Quercus robur L. with GBH of $666 \mathrm{~cm}$ and height of $47 \mathrm{~m}$ in the former manor game preserve in Nová Horka rank among the biggest autochthonous trees in the area. Populus nigra L. with GBH of $552 \mathrm{~cm}$ and height of $43 \mathrm{~m}$ (Odra), Fraxinus excelsior L. with GBH of $514 \mathrm{~cm}$ (the Studenec Pond System) and Salix x rubens Schrank with GBH of $580 \mathrm{~cm}$ and height of $14 \mathrm{~m}$ (Odra) rank among other giant trees. Ulmus glabra Huds. Em. Moos with GBH of $389 \mathrm{~cm}$, Acer campestre L. with $371 \mathrm{~cm}$, Acer platanoides L. with $335 \mathrm{~cm}$, Alnus glutinosa (L.) Geartn. with GBH of $340 \mathrm{~cm}$ or Cerasus avium (L.) Moench with GBH of $330 \mathrm{~cm}$ (wetlands of the Lišći potok/the Lisci Stream/), which occurs, however, in a very bad condition belong also to giant trees of its species. Maximum heights of particular tree species range between 25 and $57 \mathrm{~m}$. Poplars rank among the tallest trees. Found specimens 
of Populus $x$ canadensis Moench measured $57 \mathrm{~m}$ (Odra) and of Populus nigra L. $55 \mathrm{~m}$ (Odra) (Tab. 6).

\section{Evaluation of health condition}

In the PLA Poodří, mainly vital trees occur, namely $49 \%$ trees are in excellent and $21 \%$ in very good health condition. Some $18 \%$ trees are slightly damaged. In $10 \%$ trees, there is visible heavy damage, $2 \%$ trees die away and only $1 \%$ mapped trees are dead. The occurrence of wood-destroying fungi (13\%) and cambioxylophagous insects (9\%) count for the main causes resulting in the impaired health condition. Due to abiotic factors $8 \%$ trees were damaged. As for abiotic factors, drought caused cracks in the bark of trunks (particularly in the western part of the area $-5.2 \%$ ). Also leaves of the trees turned yellow prematurely. Frost caused cracks on tree trunks, some trees were damaged by lightning, strong wind or their roots were exposed due to the erosive activity of a watercourse. About $2 \%$ trees were damaged by man. It refers mainly to damage when iron hooks were driven to trees or barbed wires were grown into trees or trees were damaged by unsuitably situated hunting seats (e.g. high seats). Viroses (virus diseases) weaken $0.1 \%$ trees and canker (burrs) occurs in $2 \%$ trees. The occurrence of parasitic Viscum album L. was noted most frequently in Populus $x$ canadensis Moench. In the western part, the pest was also noted in several lime trees (Tilia cordata Miller and Tilia platyphyllos Scop.). The majority of trees are overgrown by mosses and lichens.

The rate of drying up was monitored in crowns of IWS. Trees in the studied area suffer mainly from dieback (drying up crowns up to 25\%). In the eastern part, trees are more susceptible to drying ( $35 \%$ trees suffer from a various degree of drying up).

Physiological vitality is full in 50\% registered trees, sufficient vitality is shown in $26 \%$ trees, insufficient in $20 \%$ trees and $4 \%$ trees are without any vitality. From the aspect of physiological age, the majority $(61 \%)$ of specimens are fully developed mature trees, $32 \%$ are senescent trees, $4 \%$ trees approach their death and 3\% are dying and dead trees.

Tilia platyphyllos Scop., Alnus glutinosa (L.) Geartn., Fraxinus excelsior L., Carpinus betulus Z., Acer pseudoplatanus L., Tilia cordata Miller, Acer campestre L. and Quercus robur L. thrive best. Excellent health conditions are also evident in the introduced trees such as Quercus rubra L. or Platanus x acerifolia (Aiton) Willd.. On the contrary, the worst health conditions are demonstrated in the following species: introduced Robinia pseudoacacia L. and Aesculus hippocastanum L., which is attacked by Cameraria ohridella Deschka \& Dimic, Salix x rubens Schrank, Acer platanoides L. and Salix fragilis L..

\section{Categorization of trees according to the principle of sustainable care}

Some 43 trees were included in the category of veterans and 257 trees in the category of representatives. The GBH minimum limit to classify the trees into these categories was set to $400 \mathrm{~cm}$. In field surveys, the GBH limit was lowered to $250 \mathrm{~cm}$ in some species. It refers to field maple (Acer campestre L.), Norway maple (Acer platanoides L.), black alder (Alnus glutinosa (L.) Geartn.), hornbeam (Carpinus betulus Z.), wild cherry (Cerasus avium (L.) Moench), crack willow (Salix fragilis L.), Scotch elm (Ulmus glabra Huds. Em. Moos) and European white elm (Ulmus laevis Pallas).

Quercus robur L. (9 veterans and 62 representatives) and Salix alba L. (19 veterans and 46 representatives) are the most abundant species in these two categories. In total 1283 trees were included in the category of successors. Remaining 1791 trees belong to the category of candidates. Total ratio between particular categories, i.e. veterans (V), representatives $(\mathrm{R})$, successors $(\mathrm{S})$ and candidates $(\mathrm{C})$ in all registered trees is on average 1 : 6: 30: 42 (Tab. 6). 


\section{The occurrence of IWS in GTG in the riparian zone of the Odra River and its tributaries (in the PLA Poodří)}

The total area of the geobiocoenologically mapped riparian zone of watercourses amounts to 553.19 ha, of which the largest part, namely $57.3 \%$ (317.09 ha) is occupied by the GTG Ulmi-fraxineta carpini sup. followed by Querci roboris-fraxineta sup. with $27.6 \%$ (152.95 ha), Alni glutionosae-saliceta sup. with $10.1 \%$ (55.96 ha), Ulmi-fraxineta populi sup. with $2.3 \%$ (12.78 ha), Saliceta fragilis inf. with $1.8 \%$ (9.92 ha) and the smallest part $0.8 \%$ (4.49 ha) belongs to contact GTGs (Buček et al. 2000).

In the riparian zone (which is geobiocoenologically mapped), 806 trees belonging to 21 species, hybrids and cultivars +1 species-undetermined genus Malus Mill. were registered. The largest proportion shows Salix alba L. with 162 trees (20\%) (Proportion of other species - see Tab. 7).

The largest species diversity occurs at sites of Ulmi-fraxineta carpini sup. with 21 species +1 genus (Malus sp. Mill) followed by Querci roboris-fraxineta sup. with 14 species and Alni glutionosae-saliceta sup. with 9 species, Ulmi-fraxineta populi includes 5 species and the smallest proportion shows Saliceta fragilis inf. with 3 species and a contact GTG with 2 species and 1 genus (Populus sp. L.) (see Tab. 7).

Average density of IWS for the studied part of the mapped area amounts to 1.5 trees/ha. The density in particular GTG varies from 0.6 to 1.6 trees/ha. GTGs of Alni glutionosaesaliceta sup., Querci roboris-fraxineta sup., Ulmi-fraxineta carpini sup. and Ulmi-fraxineta populi sup. show considerably balanced values (from 1.4 to 1.6 trees/ha). The largest density, see 1.6 trees/ha is demonstrated by Ulmi-fraxineta populi sup. Ulmi-fraxineta carpini sup. shows an average value of 1.5 trees/ha. Other GTGs, namely Alni glutionosaesaliceta sup. and Querci roboris-fraxineta sup. with 1.4 trees/ha, a contact GTG with 0.9 trees/ha and Saliceta fragilis inf. with 0.6 trees/ha (ie 1 tree/1.7 ha) show below-average values.

From the viewpoint of maximum GBH according to particular geobiocoene type groups (GTG) the biggest trees of particular species occur mainly in Ulmi-fraxineta carpini sup. with the exception of Salix x rubens Schrank, Ulmus glabra Huds. Em. Moos, Ulmus laevis Pallas and Acer campestre L.. In Querci roboris-fraxineta sup, the biggest Salix $x$ rubens Schrank with the GBH of $580 \mathrm{~cm}$, Acer campestre L. with $270 \mathrm{~cm}$ and Ulmus laevis Pallas with $620 \mathrm{~cm}$. The biggest Ulmus glabra Huds. Em. Moos with GBH of $389 \mathrm{~cm}$ occurs in the GTG of Alni glutionosae-saliceta sup..

\section{DISCUSSION}

\section{Comparison of the abundance and diversity of IWS with other areas with similar site conditions}

Results achieved in the PLA Poodři can be compared with results of a survey carried out in riparian stands along watercourses belonging to the extensive area of the Odra River basin (without the PLA Poodří), which was carried out in 1998 - 2001 (Maděra et al., 2000; Maděra, Dreslerová, Rychtecká, 2002) and of the inventory of big trees in the Dyje-Morava River floodplain (Suchyňová, 2002). There are 1,243 IWS registered in the riparian zone of watercourses in the PLA Poodří, which reaches tens of river kilometres, (Rychtecka 2004, Dreslerova 2005). In the riparian zone of watercourses in the Odra River basin, several thousands river kilometres have been mapped up to now. Along the watercourses, 270 IWS +5 alleys have been registered (Madera et al, 2000). The occurrence of RT in the riparian zone of the PLA Poodŕi is many times higher. One of courses of the fact is high rate of 
anthropogenic impacts on watercourses in the Odra River basin, particularly in wide valley alluvia. Man effects on the occurrence of big trees along watercourses become also evident in the actual PLA. Along watercourses subject to intense river channel reconstruction, the occurrence of IWS is zero (e.g. Bílovka, Sedlnice, Bartošovický potok) (Rychtecká, 2006). The density of IWS in the whole part of the PLA Poodři is 1 tree/2.5 ha whereas the highest concentration of IWS occurs in the riparian zone of a watercourse. In the Dyje-Morava floodplain, in the small area of Pohansko south of Břeclav, the density of big trees is 1 tree/4 ha (Suchyňová, 2002).

In the riparian zone of the PLA Poodři, there are 21 species, hybrids and cultivars +1 genus Malus Mill (Tab. 7), which is much lower diversity than within the Odra River watershed where 33 species, hybrids and cultivars of woody plants are registered (Madera et al, 2000). This high species abundance is partly caused by the large extent of the area from lowlands to foothills including wide and narrow stream alluvia and various site conditions resulting from that and partly by the occurrence on the boundary of three biogeographical sub-provinces: West-Carpathian, Polonian and Hercynian. In wide alluvial plains of the Odra basin, there are 18 woody species of which 3 belong to shrubs and 15 to arborescent species. In narrow floodplains, in total 30 species are registered of which 3 are shrubs and 27 trees. Comparing the diversity in wide valley alluvia of the Odra basin and in the riparian zone of the PLA Poodrí we can find that the diversity of arborescent species is higher in the PLA Poodŕí. Thus, while comparing the diversity according to particular GTG in the Odra basin and in the riparian zone of the PLA Poodrí, it is obvious that the geobiocoenes in the PLA Poodří show higher species diversity (Fig. 3).

The databank of the PLA Poodři amounts to 26 various species and hybrids +4 speciesunspecified genera of Malus sp. Mill, Betula sp. L., Populus sp. L. and Salix sp. L.. In the Dyje-Morava floodplain, some 10 species of IWS were registered (Quercus robur L., Carpinus betulus Z., Ulmus laevis Pallas, Pyrus pyraster (L.) Burgsd., Salix alba L., Populus alba L., Acer campestre L., Quercus cerris L., Fraxinus angustifolia Vahl. and Crataegus monogyna Jacq.) (Suchyňová, 2002).

\section{Fig.3: Comparison of the biodiversity of particular GTG in the riparian zone of the PLA Poodří and in the Odra river basin}

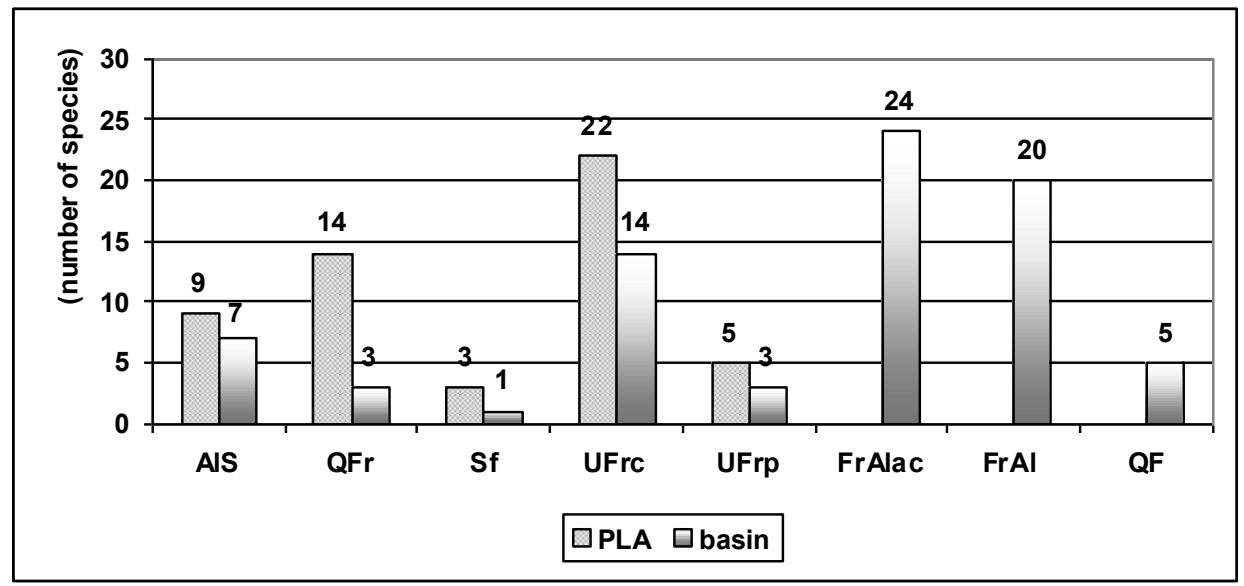




\section{Comparison of health condition}

In the area under study, Quercus robur L. is the most abundant species creating the substantial part of IWS in the area. Therefore, it is important to evaluate its health condition. For the purpose of comparison, we used data obtained from the inventory of IWS in the Dyje-Morava floodplain (Suchyňová, 2002). In the PLA Poodří, the present condition of Quercus robur L. appears to be excellent in more than $50 \%$ trees, in $26 \%$ very good health condition, in 17\% slightly damaged, heavy damage occurs in 5\% trees and only $1 \%$ trees shows dying or dead trees (Fig. 4). As for damage to crowns, drying up crowns up to $25 \%$ is most frequent, namely in $18 \%$ trees. Remaining $12 \%$ trees showed more extensive damage to crowns concerning drying up crowns (over 25\%). The other $70 \%$ trees did not show symptoms of drying up. Damage to Quercus robur L. trunks occurred only in $28 \%$ trees. The most frequent damage occurred in form of: cracks $(6 \%)$, insect pest $(7 \%)$ and wood-destroying fungi (5\%). As for wood-destroying fungi, it referred mainly to Phellinus robustus (P. Karst) Bourdot \& Galzin and Daedalea quercina (L.) Pers and partly to Laetiporus sulphurous (Bull.: Fr.), Bjerkandera adusta (Willd. ex Fr.) P. Karst, Armillaria mellea (Vahl) P. Kumm., Trametes hirsuta (Wulf. Ex Fr.) and Ganoderma resinaceum (Boud.).

Fig.4: Health conditions of Pohansko and the PLA Poodří

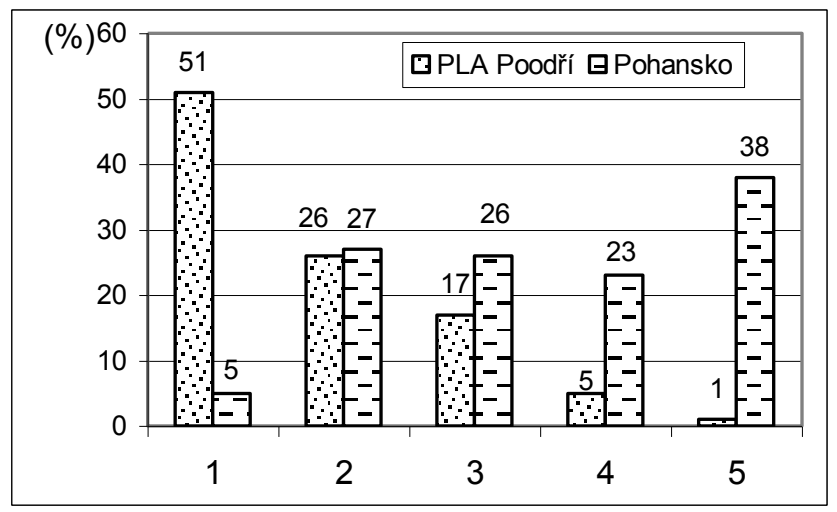

The majority of oak trees in the area of Pohansko in the Dyje-Morava floodplain are approaching their end of life. The situation could be partly caused by river channel reconstruction of the Dyje and the Morava rivers in the 1970s, which meant decrease in the groundwater level and old oak trees were not able to adapt to these changes. There are $38 \%$ dying or dead trees, $23 \%$ heavily damaged trees, $27 \%$ trees occur in very good health condition and $26 \%$ trees are slightly damaged. Only $5 \%$ of the total number of trees occur in a very good health condition. At present, $36 \%$ trees are quite dry, $30 \%$ trees show dry crowns (more than half crown). On the other hand, only $13 \%$ trees show partly dry crowns (maximally one quarter of crowns). Wood-destroying fungi were found in $86 \%$ trees most frequent being Fistulina hepatica (Schaeff.) With., Phellinus robustus (P. Karst) Bourdot \& Galzin, Daedalea quercina (L.) Pers. and Laetiporus sulphureus (Bull.) (Suchyňová, 2002).

\section{Comparison of growth parameters of registered trees with other regions}

a) Areas with the same site conditions (characteristics)

Important woody species in the PLA Poodŕi were compared with large trees in the riparian zone of the whole Odra River basin. From the viewpoint of maximum GBH, it was 
possible to compare 13 woody species, of which 6 species in the PLA Poodři reach higher dimensions than trees found in the Odra basin (Tab. 8). Two willows Salix $x$ rubens Schrank with the GBH of $700 \mathrm{~cm}$ and one linden Tilia platyphyllos Scop. also with the GBH of $700 \mathrm{~cm}$ count for the biggest trees in the Odra basin. Alnus glutinosa (L.) Geartn. with the GBH of 405 and $408 \mathrm{~cm}$ and height about 30 and $25 \mathrm{~m}$ as well as two big poplars Populus nigra L. with the GBH of 628 and $680 \mathrm{~cm}$ belong to interesting trees.

Considerable number of trees in the PLA Poodři exceeds trees from the Dyje-Morava floodplain in growth parameters. Fraxinus excelsior L. with the GBH of $514 \mathrm{~cm}$ or Ulmus laevis Pallas with the GBH of $620 \mathrm{~cm}$ belong among them. Acer campestre L. with the GBH of $507 \mathrm{~cm}$, Carpinus betulus Z. with a unique GBH of $482 \mathrm{~cm}$, Quercus robur L. with $806 \mathrm{~cm}$, Pyrus pyraster (L.) Burgsd. with GBH $303 \mathrm{~cm}$ and Populus alba L. with $606 \mathrm{~cm}$ are among large trees of the Dyje-Morava floodplain (Tab. 8) (Maděra et al. 2006).

\section{b) Other areas}

Databases of "memorable trees" (MT) of the Czech Republic were selected for the purpose of comparison. At present, attention is paid only to protected trees which are included in the lists of MT. IWS of the PLA Poodř́ can be divided into two groups. In the first group, those species occur, which are the abundant subject of interest such as memorable trees and, vice versa, in the second group, those trees occur, which are less abundant in the list of memorable trees or do not occur there at all. In the most abundant species of memorable trees such as pedunculate oak, lime tree, sycamore or European ash, dimensions of trees registered in the studied area range at the lower limit of trees registered in the list of memorable trees in the CR (Reš, 1998) (Tab. 9).

Girth characteristics measured in the region of the PLA Poodri were compared with those of trees registered in the list of "Champion trees of the British Isles" (Mitchell et al., 1990, Johnson et al., 2003) and with the list of woody species from Belgian parks (Baudouin, 1992) (Tab. 9). A number of trees found in the PLA Poodři can be boldly compared with sources mentioned above. As for woody species occurring at the upper limit of dimensions in the registration of British Isles and Belgian parks it refers to Salix alba L. with the GBH of $720 \mathrm{~cm}$, Ulmus laevis Pallas with $620 \mathrm{~cm}$, Ulmus glabra Huds. Em. Moos with $389 \mathrm{~cm}$, Salix fragilis L. with $398 \mathrm{~cm}$ and Salix $x$ rubens Schrank with the GBH of $580 \mathrm{~cm}$. Also representatives of poplars, oaks or ash and lime trees found in the PLA Poodŕi belong among the largest trees due to their GBH as compared with the registration of British Isles and Belgian parks. It concerns Quercus robur L. with the GBH of $666 \mathrm{~cm}$, Tilia cordata Miller with $430 \mathrm{~cm}$ and Fraxinus excelsior L. with $514 \mathrm{~cm}$. Sources mentioned above are exceeded by Salix $x$ rubens Schrank with the GBH of $580 \mathrm{~cm}$ and Populus nigra L. with the GBH of $552 \mathrm{~cm}$ and, therefore they belong among the largest trees of their species in Europe. Allochthonous Platanus $x$ acerifolia (Aiton) Willd. with the GBH of $780 \mathrm{~cm}$ reaches considerable dimensions there. However, also other species can be compared with sources mentioned above: Acer platanoides L. with the GBH of $335 \mathrm{~cm}$, Alnus glutinosa (L.) Geartn. with $340 \mathrm{~cm}$, Acer campestre L. with $371 \mathrm{~cm}$ and also Cerasus avium (L.) Moench with the GBH of $330 \mathrm{~cm}$. Unfortunately, this tree is registered as dying. Aesculus hippocastanum L. with the GBH of $354 \mathrm{~cm}$, Quercus rubra L. with $228 \mathrm{~cm}$ and Robinia pseudoacacia $\mathrm{L}$. with the GBH of $265 \mathrm{~cm}$ occur at the lower limit.

\section{Description of succession stages on the basis of occurrence of important woody species in the riparian zone}

The occurrence of IWS in the landscape can demonstrate the developmental stage of succession at the given floodplain site. In the western part of the area, the highest 
percentage proportion belongs to Salix alba L. with $20.1 \%$, the greatest proportion showing in GTG Saliceta - fragilis inf. (50\%) as well as in Alni glutinosae-saliceta sup. (26\%), this corresponds to the fact that it refers to the initial succession stages of a soft-wood floodplain forest. From the viewpoint of GTG, also Salix $x$ rubens Schrank shows again the highest proportion (33\%) in Saliceta fragilis inf. and in Alni glutinosae-saliceta sup. (21\%). With advanced stages of succession the proportion of willow decreases. Quercus robur L. is a dominant species in final stages of succession of hardwood floodplain. The species proves its increasing proportion from Alni glutinosae-saliceta sup. (9\%) over Querci roboris-fraxineta sup. (12.6\%) to Ulmi-fraxineta carpini sup. (12.7\%), representing the final stage of succession in wide alluvial plains.

\section{Principles of permanent care of IWS}

The principle of permanent care of IWS consists of the creation of the suitable pyramid of abundances among particular categories: veterans, representatives, successors and candidates. At present, the ratio among particular categories is on average as follows: 1: 6 : $30: 42$. To determine management, veterans and representatives are combined and, thus, we obtain the following ratio: 1:4:6 (V+R: $\mathrm{S}: \mathrm{C})$.

Generally, the condition can be evaluated as favourable because it predicates that representative trees have (in reserve) a sufficient number of successors or candidates. Particularly high number of successors is important. It refers to trees, which show excellent health conditions representing therefore promising trees. Great attention, care and protection should be paid to this category. As for the category of candidates it is necessary to register a sufficient number of the trees optimally distributed throughout the area. It is supposed that only $1 / 3$ of the trees will experience the stage of representatives because $1 / 3$ of candidates is represented by trees of a very good health conditions. The aim is to create the similar pyramid of abundances of particular categories. Therefore, it is necessary to plant new trees in sites of a suitable locality. It refers to extensive meadows and banks of some watercourses. The protection of natural regeneration and young trees from game and the collection of vegetative and generative material from genetically certified plants are important to preserve the gene pool of woody species. To improve the vitality of trees occurring in localities with low groundwater level it is necessary to carry out effective revitalization measures.

\section{CONCLUSION}

Landscape-ecological functions of floodplain communities in alluvial plains are not replaceable. In the past, areas of original floodplain forests of the PLA Poodŕi gradually decreased due to uprooting and burning in favour of agricultural land. Wood coming from these forests was used as the source of fuel and building timber. At present, forest land of the PLA Poodŕi occupies only 10\%. Trees outside the forest are of an important use. According to a survey carried out in this area many important woody species (IWS) occur in the PLA Poodří.

There can be numerous species found there, which exceed the same species from other floodplain sites in the CR due to their growth parameters being even comparable with other European localities. Species diversity of IWS in the riparian zone of floodplains is many times higher than in the surrounding landscape whereas higher species diversity occurs in narrower alluvial plains of smaller watercourses. In wide alluvial plains, the highest diversity is represented by the GTG Ulmi-fraxineta carpini sup. 
The density of IWS in the PLA Poodři is quite unique (on average 1 tree/2.5 ha) being considerably balanced in particular groups of geobiocoenes. The highest density (1.6 trees /ha) occurs in Ulmi-fraxineta populi sup. Because trees the $\mathrm{GBH}$ of $200 \mathrm{~cm}$ are included there it is probable that the high rate of the occurrence of IWS will be preserved even in the future. In the riparian zone of the watercourse, there is higher concentration of IWS than in other biotopes, which is given by the method of management in the floodplain and by a fact that a preserved natural watercourse occurs in the given area.

To ensure species diversity and rich occurrence of IWS in the landscape a pyramid composed of veterans, representatives, successors and candidates was defined for every species. Numerical proportion of particular species increases in the direction from veterans and representatives over successors to candidates. Particularly the abundant number of successors represented by trees of excellent health conditions reaching above-average, however, not extraordinary dimensions is substantial. Their importance consists in the permanent provision of representatives in the landscape. Preservation of the species spectrum of big trees is important to maintain the gene pool of autochthonous populations and biodiversity in the landscape.

\section{ACKNOWLEDGMENTS}

The research was funded from the Research Project of the Faculty of Forestry and Wood Technology, Mendel University of Agriculture and Forestry in Brno - Partial task "Characteristic of the condition and development of floodplain geobiocoenoses in Moravian alluvial plains” (Reg. no. MSM: 6215648902).

\section{REFERENCES:}

Anderson, M., G., Walling, D.E., \& Bates, P.D. (1996). Floodplain processes. John Willy \& Sons, Chichester, New York, Brisbane, Toronto, Singapore.

Baudoin, J. C., Spoelberch, de Ph., Meulder, van J. \& Jacobs, R. (1992). Bomen in Belgie. Dendrologische inventaris 1987-1992. 511 pp, Stichting Spoelberch - artois.

Baker, J.B. (1977). Tolerance of planted hardwoods to spring flooding. S.J.Appl.For. 1, 2325.

Bornette, G., Amoros, C. (1996). Disturbance regimes and vegetation dynamics: role of floods in riverine wetlands. Journal of Vegetation Science 7:615-622.

Brzobohatý, J. (2000). Ekologicky významné segmenty krajiny pobřežní zóny nivy Dyje $v$ oblasti Soutoku.Thesis. MZLU v Brně, Brno.

Buček, A., Lacina, J. (1999). Geobiocenologie II. MZLU v Brně.

Buček, A. (2000). Geobiocenologické mapování přibřežního pásma vodních toků ve správě Povodi Odry. Text report + maps. MZLU v Brně, Brno.

Buček, A. (2000). Geobiocenologické mapování př́břežního pásma vodních toků ve správě Povodi Odry, maps, Brno.

Culek, M. (1996). Biogeografické členěni České republiky. Enigma, Praha, 347 pp + 1 map. Dejčmar, V. (1969). Posouzení zdravotního stavu památných stromů na území LZ Břeclav a návrh opatření na jejich ochranu. Thesis. Fakulta lesnická, Vysoká škola zemědělská $\mathrm{v}$ Brně. 
Demek, J. (1987a). Obecná geomorfologie. Academia, Praha, 476 pp.

Dreslerová, J. (2005). Krajinně-ekologické hodnocení významných dřevin v západní části CHKO Poodři a jejich management. Thesis. Ústav lesnické botaniky, dendrologie a geobiocenologie, fakulta Mendlovy zemědělské a lesnické univerzity v Brně, Brno.

Dreslerová, J. (2006). Významné dřeviny ve vybraných oblastech širokých údolních niv. In.: Měkotová, J., Štěrba, O. (Eds.): Sborník Řični krajina, PřF UP v Olomouci, Olomouc.

Holobrádek, P. (1952). Mamutí stromy při ústí Dyje. Lidé a země, 1: 202-203. Praha

Holobrádek, P. (1958). Mamutí stromy v reviru Pohansko na jižní Moravě. Zpr. Mus. a Vlastiv. Kroužku při Domu Osv. Břeclav 1958/(3): 10-11.

Chadt, J.E. (1913). Staré a památné stromy v Čechách, na Moravě a ve Slezsku. Vlastním nákladem, Písek.

Jongman, R.H.G., Külvik, M. \& Kristiansen, I. (2004). European ecological networks and greenways. Landscape and Urban Planning 68: 305 - 319.

Kneblová-Vodičková in Opravil (1999). Z historie údolní nivy v CHKO Poodři $a v$ přilehlém území. Poodří - Současné výsledky výzkumu v chráněné krajinné oblasti Poodří, Společnost přátel Poodří, Ostrava.

Korpeí, Š. (1989). Virgin forests of Slovakia (in Slovak). Veda, Bratislava, 328 pp.

Larcher, W. (1995). Physiological plant ecology. 3rd Edn., Springer-Verlag, Berlin, 506 pp.

Lonsdale, D. (1999). Tree Hazard Assessment and Management. HUSO, London.

Maděra, P. (2002). Mohutné dřeviny, krajinný ráz a biodiverzita. In.: Míchal, I. (Ed.): Tvár naši země - krajina domova, svazek 5. 125-130 pp. Ochrana krajiny. Sborník z konference „Tvář naší země - krajina domova“ Praha, Průhonice

Maděra, P., Buček, A., Štykar, J., Čermák, P., Hrubý, Z., Klečka, J., Král, K. \& Vojtek, M., (2000). Databank of important tree species in the Odra river watershed riparian zone of streams. Čas. Slez. Muz. Opava (A), 49-2000/3:239-246.

Maděra, P., Dreslerová, J., Rychtecká, P. \& Suchyňová, G. (2003). Nivy a mohutné dřeviny. Veronica č. 2/2003, Regionální sdružení ČSOP Brno, pp 16-17.

Maděra, P., Dreslerová, J. \& Rychtecká, P. (2002). Významné dřeviny podél vodních toků v Poodří. Poodři - časopis obyvatel Horni Odry No. 1/2002, Společnost přátel Poodří, Ostrava. 14-18.

Maděra, P., Dreslerová, J. \& Rychtecká, P. (2002). Významné dřeviny příbřežního pásma vodnich toků v povodi Odry. Sborník z konference Ekotrend, České Budějovice. C13-C17.

Maděra, P., Pejchal, M., Dreslerová J., Krejčiř́ík, P., Klimánek, M., Mikita, T. \& Lička, D. (2006). Remarkable trees. Dendrological guide to the Dolní Morava Biosphere Reserve. BR Dolní Morava, Břeclav, 51 p.

Malanson, G.P. (1995). Riparian landscapes. - Cambridge Univ. Press

Mitchell, A. F., Hallet, V. E. \& White, J. E. J. (1990). Champion trees in the British Isles. Forestry commission, Field book 10, 33 pp, London: HMSO, $3^{\text {rd }}$ ed.

Opravil, E. (1999). Z historie údolní nivy v CHKO Poodři a v přilehlém území. Poodří Současné výsledky výzkumu v chráněné krajinné oblasti Poodří, Společnost přátel Poodří, Ostrava.

Polehla, P. (2002). Mohutné dřeviny v Př́rodní památce Obora při Náměšti nad Oslavou. Diplomová práce, Brno, ÚLBDT LDF MZLU v Brně. 
Polišenská, M. (2002). Solitérni strom v krajině. (Modelový objekt - Pohansko). Thesis. Zahradnická fakulta. MZLU v Brně, Lednice na Moravě.

Read, H. (2000). Veteran Trees: A guide to good management. English Nature, Peterborough, $176 \mathrm{p}$.

Reš, B. (1998). Památné stromy. AOPK ČR. 64 pp.

Rychtecká, P. (2004). Krajině-ekologické hodnocení významných dřevin ve východní části CHKO Poodř́ a jejich management. Thesis. Ústav lesnické botaniky, dendrologie a typologie, fakulta Mendlovy zemědělské a lesnické univerzity v Brně, Brno.

Rychtecká, P. (2006). Výskyt mohutných dřevin v STG širokých údolních niv. In.: Měkotová, J., Štěrba, O. (Eds.), Sbornik Říčni krajina, PřF UP v Olomouci, Olomouc.

SCHKO (1999). Plán péče. Depozitum in Správa chráněné krajinné oblasti Poodří.

Suchyňová, G. (2002). Inventarizace významných dřevin Dyjskomoravské nivy a jejich management. Thesis. Ústav lesnické botaniky, dendrologie a typologie, fakulta Mendlovy zemědělské a lesnické univerzity v Brně, Brno.

Wenger, E.L., Zinke, A. \& Gutzweiler, K.A. (1990). Present situation of the European floodplain forests. Forest Ecology and Management, 33-34, 5-12. 

Table 6: Species composition of IWS and their abundance with growth parameters and categories according to management in the PLA Poodří

\begin{tabular}{|c|c|c|c|c|c|c|c|c|}
\hline & Species & Veterans & $\begin{array}{c}\text { Repre- } \\
\text { sentatives }\end{array}$ & Successors & $\begin{array}{c}\text { Candi- } \\
\text { dates }\end{array}$ & Number of trees & Girth range & Height \\
\hline 1 & Acer campestre & $*$ & 7 & 11 & 12 & 30 & $100-371$ & $14-38$ \\
\hline 2 & Acer platanoides & $*$ & 7 & 1 & 5 & 13 & $200-335$ & $12-40$ \\
\hline 3 & Acer pseudoplatanus & $*$ & 0 & 14 & 13 & 27 & $155-310$ & $23-45$ \\
\hline 4 & Aesculus hippocastanum & $*$ & $*$ & $*$ & 37 & $11+1$ alley $(26) \rightarrow 37$ & $150-354$ & $10-36$ \\
\hline 5 & Alnus glutinosa & $*$ & 10 & 129 & 68 & $159+2$ alleys $(48) \rightarrow 207$ & $73-340$ & $17-44$ \\
\hline 6 & Betula pendula & $*$ & $*$ & 3 & 3 & 6 & $130-291$ & $13-26$ \\
\hline 7 & Betula sp. & $*$ & $*$ & $*$ & 1 & 1 & 350 & 21 \\
\hline 8 & Carpinus betulus & $*$ & 2 & 24 & 18 & 44 & $136-292$ & $18-39$ \\
\hline 9 & Cerasus avium & $*$ & 1 & 6 & 10 & 17 & $182-330$ & $16-30$ \\
\hline 10 & Fagus sylvatica & $*$ & 1 & 6 & 1 & 8 & $256-480$ & $25-38$ \\
\hline 11 & Fraxinus excelsior & $*$ & 5 & 217 & 166 & $351+4$ alleys $(37) \rightarrow 388$ & $198-514$ & $15-49$ \\
\hline 12 & Larix decidua & $*$ & $*$ & $*$ & 5 & 6 & $157-196$ & $25-41$ \\
\hline 13 & Malus sp. & 1 & 1 & 0 & 1 & 3 & $211-225$ & $8-11$ \\
\hline 14 & Platanus $x$ acerifolia & $*$ & $*$ & $*$ & 4 & 4 & $310-780$ & $26-36$ \\
\hline 15 & Populus balsamifera & $*$ & $*$ & $*$ & 1 & 1 & 254 & 35 \\
\hline 16 & Populus nigra & $*$ & 20 & 42 & 82 & $123+1$ alley $(21) \rightarrow 144$ & $217-552$ & $22-47$ \\
\hline 17 & Populus sp. & 2 & 5 & 9 & 38 & 54 & $219-490$ & $20-55$ \\
\hline 18 & Populus $x$ canadensis & $*$ & 4 & 37 & 259 & $106+1$ alley $(183) \rightarrow 289$ & $220-500$ & $24-57$ \\
\hline 19 & Quercus robur & 9 & 62 & 508 & 532 & $1066+2$ alleys $(44) \rightarrow 1110$ & $140-666$ & $17-48$ \\
\hline 20 & Quercus rubra & $*$ & $*$ & $*$ & 1 & 1 & 228 & 31 \\
\hline 21 & Robinia pseudoacacia & $*$ & $*$ & $*$ & 12 & 22 & $130-720$ & $27-39$ \\
\hline 22 & Salix alba & 19 & 46 & 77 & 277 & $326+3$ alleys $(92 s) \rightarrow 418$ & $130-720$ & $1,3-43$ \\
\hline 23 & Salix fragilis & 3 & 34 & 8 & 21 & 68 & $140-398$ & $1,4-29$ \\
\hline 24 & Salix $x$ rubens & 7 & 16 & 17 & 102 & 142 & $135-580$ & $1,1-37,5$ \\
\hline 25 & Salix sp. & $*$ & $*$ & 6 & 7 & 13 & $215-420$ & $8-30$ \\
\hline 26 & Tilia cordata & $*$ & 5 & 112 & 80 & 197 & $200-430$ & $21-47$ \\
\hline 27 & Tilia platyphyllos & $*$ & 2 & 43 & 14 & 59 & $200-436$ & $16-46$ \\
\hline 28 & Ulmus glabra & 1 & 14 & 8 & 12 & 35 & $208-389$ & $26-45$ \\
\hline 29 & Ulmus laevis & 1 & 15 & 5 & 7 & 28 & $196-620$ & $27-42$ \\
\hline 30 & Ulmus minor & $*$ & 0 & 0 & 2 & 2 & $315-350$ & $20-30$ \\
\hline & & 43 & 257 & 1283 & 1791 & Total 3374 trees & & \\
\hline
\end{tabular}


Table 7: Species and numerical proportion of IWS in the GTG of a riparian zone in the PLA Poodř́

\begin{tabular}{|c|c|c|c|c|c|c|c|}
\hline GTG & AIS & QFr & Sf & UFrc & UFrp & Contact & Total \\
\hline \multicolumn{8}{|l|}{ Species } \\
\hline Acer campestre & * & 2 & * & 2 & * & * & 4 \\
\hline Acer platanoides & * & * & * & 4 & * & * & 4 \\
\hline Acer pseudoplatanus & * & 1 & * & 3 & * & * & 4 \\
\hline Aesculus hippocastanum & * & * & * & 2 & * & * & 2 \\
\hline Alnus glutinosa & * & 2 & * & 5 & * & * & 7 \\
\hline Betula pendula & * & 2 & * & 1 & * & * & 3 \\
\hline Carpinus betulus & * & * & * & 6 & * & * & 6 \\
\hline Cerasus avium & * & $*$ & * & 3 & * & * & 3 \\
\hline Fraxinus excelsior & 8 & 20 & * & 48 & 2 & * & 78 \\
\hline Malus sp. & * & * & * & 3 & ${ }^{*}$ & * & 3 \\
\hline Populus $x$ canadensis & 7 & 16 & * & 45 & 10 & 2 & 80 \\
\hline Populus balzamifera & * & ${ }^{*}$ & * & 1 & ${ }^{*}$ & * & 1 \\
\hline Populus nigra & 4 & 20 & 1 & 54 & 4 & * & 83 \\
\hline Populus sp. & 9 & 44 & * & 21 & 2 & 1 & 77 \\
\hline Quercus robur & 7 & 27 & * & 61 & 1 & 1 & 97 \\
\hline Salix alba & 21 & 28 & 3 & 108 & 2 & * & 162 \\
\hline Salix fragilis & 3 & 18 & * & 30 & * & * & 51 \\
\hline Salix $x$ rubens & 17 & 19 & 2 & 43 & * & * & 81 \\
\hline Salix sp. & * & 4 & * & 7 & * & * & 11 \\
\hline Tilia cordata & 4 & 8 & * & 24 & * & * & 36 \\
\hline Tilia platyphyllos & * & 2 & * & 4 & * & * & 6 \\
\hline Ulmus glabra & 1 & 2 & * & 1 & * & * & 4 \\
\hline Ulmus laevis & * & * & * & 2 & * & * & 2 \\
\hline Ulmus minor & * & * & * & 1 & * & * & 1 \\
\hline TOTAL & 81 & 215 & 6 & 479 & 21 & 4 & 806 \\
\hline
\end{tabular}


Table 8: Comparison in growth parameters of woody species in the PLA Poodří with the biggest trees from riparian zone of the Odra river basin (without PLA Poodř́; Maděra et al., 2000) and from the Dyje-Morava floodplain (Suchyňová, 2002, Polišanská, 2002, Dreslerová, 2006)

\begin{tabular}{|c|c|c|c|c|c|c|}
\hline \multirow[t]{2}{*}{ Species } & \multicolumn{2}{|c|}{ PLA Poodří } & \multicolumn{2}{|c|}{$\begin{array}{c}\text { Odra river basin (without } \\
\text { PLA Poodŕí) }\end{array}$} & \multicolumn{2}{|c|}{ Dyje-Morava floodplain } \\
\hline & $\begin{array}{l}\text { Girth range } \\
(\mathrm{cm})\end{array}$ & Height (m) & $\begin{array}{l}\text { Girth range } \\
(\mathrm{cm})\end{array}$ & Height (m) & $\begin{array}{l}\text { Girth range } \\
(\mathrm{cm})\end{array}$ & Height (m) \\
\hline Acer campestre & $100-371$ & $14-38$ & - & - & $165-505$ & $14-18$ \\
\hline Acer platanoides & $200-335$ & $12-40$ & $320-346$ & 25 & - & - \\
\hline Acer pseudoplatanus & $155-310$ & $23-45$ & $220-400$ & $20-30$ & - & - \\
\hline Aesculus hippocastanum & $150-354$ & $10-36$ & $252-320$ & 25 & - & - \\
\hline Alnus glutinosa & $73-340$ & $17-44$ & $252-408$ & $20-25$ & - & - \\
\hline Carpinus betulus & $136-292$ & $18-39$ & - & - & $286-482$ & $12-22$ \\
\hline Cerasus avium & $182-330$ & $16-30$ & 235 & - & - & - \\
\hline Fraxinus excelsior & $198-514$ & $15-49$ & $265-360$ & $30-35$ & $249-260$ & 20 \\
\hline Populus nigra & $217-552$ & $22-47$ & $310-368$ & $25-40$ & 740 & - \\
\hline Populus $x$ canadensis & $220-500$ & $24-57$ & $350-420$ & - & - & - \\
\hline Quercus robur & $140-666$ & $17-48$ & $220-630$ & $25-40$ & $210-806$ & $7-28$ \\
\hline Salix alba & $130-720$ & $1,3-43$ & $285-345$ & 30 & $280-628$ & $6,5-28$ \\
\hline Salix fragilis & $140-398$ & $1,4-29$ & $236-320$ & $17-20$ & - & - \\
\hline Salix $x$ rubens & $135-580$ & $1,1-37,5$ & $220-700+$ & $17-30$ & - & - \\
\hline Tilia cordata & $200-430$ & $21-47$ & $320-440$ & $30-35$ & $225-762$ & $6-14$ \\
\hline Tilia platyphyllos & $200-436$ & $16-46$ & $285-410$ & 25 & - & - \\
\hline Ulmus glabra & $208-389$ & $26-45$ & $230-420$ & $25-35$ & - & - \\
\hline Ulmus laevis & $196-620$ & $27-42$ & 260 & 30 & $200-582$ & $4-32$ \\
\hline
\end{tabular}


Table 9: Comparison in growth parameters of woody species in the PLA Poodří and the biggest trees from British Isles (Mitchell et al., 1990, Johnson et al., 2003), Belgian parks (Baudouin et al., 1992) and "memorable trees" from Czech Republic (CR) (Reš, 1998, 2003; Němec a kol., 2003)

\begin{tabular}{|c|c|c|c|c|c|c|c|}
\hline \multirow[t]{2}{*}{ Species } & \multicolumn{2}{|c|}{ PLA Poodří } & \multicolumn{2}{|c|}{ British Isles } & \multicolumn{2}{|c|}{ Belgian parks } & \multirow{2}{*}{$\begin{array}{c}\text { MT from } \\
\text { CR } \\
\text { Girth range } \\
\text { (cm) }\end{array}$} \\
\hline & $\begin{array}{c}\text { Girth range } \\
(\mathrm{cm})\end{array}$ & Height (m) & $\begin{array}{c}\text { Girth range } \\
(\mathrm{cm})\end{array}$ & Height (m) & $\begin{array}{c}\text { Girth range } \\
(\mathrm{cm})\end{array}$ & Height (m) & \\
\hline Acer campestre & $100-371$ & $14-38$ & $420-465$ & $17-27$ & $200-327$ & $15-25$ & $375-480$ \\
\hline Acer platanoides & $200-335$ & $12-40$ & $332-364$ & $26-32$ & $154-385$ & $15-30$ & $410-530$ \\
\hline Acer pseudoplatanus & $155-310$ & $23-45$ & $361-823$ & $27-40$ & $315-780$ & $25-36$ & $590-830$ \\
\hline Aesculus hippocastanum & $150-354$ & $10-36$ & $568-668$ & $36-37$ & $319-678$ & $18-41$ & $120-577$ \\
\hline Alnus glutinosa & $73-340$ & $17-44$ & $235-521$ & $15-32$ & $184-400$ & $15-25$ & $230-340$ \\
\hline Betula pendula & $130-291$ & $13-26$ & $138-386$ & $26-30$ & $207-330$ & $20-25$ & - \\
\hline Carpinus betulus & $136-292$ & $18-39$ & $458-568$ & $18-30$ & - & - & - \\
\hline Cerasus avium & $182-330$ & $16-30$ & $223-533$ & $18-31$ & $304-320$ & $25-37$ & $158-404$ \\
\hline Fagus sylvatica & $256-480$ & $25-38$ & $474-681$ & $40-46$ & $453-858$ & $18-43$ & - \\
\hline Fraxinus excelsior & $198-514$ & $15-49$ & $285-1055$ & $12-38$ & $355-590$ & $20-46$ & $573-747$ \\
\hline Platanus $x$ acerifolia & $310-780$ & $26-36$ & $179-367$ & $35-48$ & - & - & $518-770$ \\
\hline Populus nigra & $217-552$ & $22-47$ & 710 & 24 & 227 & 32 & $172-808$ \\
\hline Populus $x$ canadensis & $220-500$ & $24-57$ & $242-376$ & $27-34$ & $482-620$ & $28-40$ & 335 \\
\hline Quercus robur & $140-666$ & $17-48$ & $311-1369$ & $14-45$ & $503-985$ & $10-40$ & $500-1006$ \\
\hline Salix alba & $130-720$ & $1,3-43$ & $282-747$ & $10-31$ & $345-740$ & $15-30$ & $262-788$ \\
\hline Salix fragilis & $140-398$ & $1,4-29$ & $279-637$ & $12-25$ & $157-365$ & 30 & $520-545$ \\
\hline Salix $x$ rubens & $135-580$ & $1,1-37,5$ & $352-430$ & $23-28$ & $284-400$ & $15-24$ & - \\
\hline Tilia cordata & $200-430$ & $21-47$ & $367-823$ & $16-40$ & $312-905$ & $10-35$ & $500-1122$ \\
\hline Tilia platyphyllos & $200-436$ & $16-46$ & $449-741$ & $14-37$ & $460-900$ & $10-30$ & $560-1252$ \\
\hline Ulmus glabra & $208-389$ & $26-45$ & $377-703$ & $25,5-41$ & $310-327$ & $20-34$ & $237-685$ \\
\hline Ulmus laevis & $196-620$ & $27-42$ & 241 & 19 & $215-630$ & $20-32$ & $243-470$ \\
\hline
\end{tabular}

